\title{
Cryștallization and Phase Transformation of Low Temperature Form Zirconia Prepared from Different Starting Materials
}

\author{
Yoshio Murase*, Etsuro Kato** and Hideo Matsumoto* \\ * Government Industrial Research Institute, Nagoya; Hirate-machi, \\ Kita-ku, Nagoya-shi, Japan \\ ** Nagoya Institute of Technology; Gokiso-cho, Showa-ku, Nagoya-shi, Japan
}

\begin{abstract}
Process of crystallization of zirconia synthesized from several kinds of zirconium compounds were studied by $\mathrm{X}$-ray powder diffractometry and electron microscopy. Samples used in the present study were zirconium hydroxide(NH), zirconyl oxalate(OX), zirconyl acetate(AC), zirconyl nitrate(NO), zirconyl chloride(Cl), zirconium chelate compound with mandelic acid(MA) and hydrous zirconia(Bl). They were heat treated at different temperatures between 400 and $700^{\circ} \mathrm{C}$. At the beginning of crystallization, the phases observed were following; (1) only monoclinic form in $\mathrm{Bl},(2)$ monoclinic and tetragonal forms in $\mathrm{NO}$ and $\mathrm{OX}$ and (3) tetragonal form and amorphous state in $\mathrm{MA}, \mathrm{AC}, \mathrm{NH}$ and $\mathrm{Cl}$, respectively. In the case (1) monoclinic crystals grew slowly to about $200 \AA$ by the heat treatment for 1 hour at about $700^{\circ} \mathrm{C}$. In the case (2) tetragonal crystals gradually transformed to monoclinic form and the crystallites of the monoclinic crystal grew larger than $300 \AA$ by the same heat treatment. In the case (3) tetragonal crystals grew more rapidly and the crystallite size reached to the maximum of about $400 \AA$ at about $500^{\circ} \mathrm{C}$. Above $500^{\circ} \mathrm{C}$, decrease of apparent crystallite size of tetragonal crystals and nucleation of monoclinic crystals occured simultaniously. At about $700^{\circ} \mathrm{C}$, the crystallites of monoclinic crystals grew larger than $300 \AA$ and the tetragonal crystals diminished. The presence of carbon resulted from the incomplete decomposition of parent compounds remarkably retarded both crystal growth and transformation to monoclinic form.
\end{abstract}

\section{フォシャジァイト $\left(4 \mathrm{CaO} \cdot 3 \mathrm{SiO}_{2} \cdot \mathrm{H}_{2} \mathrm{O}\right)$ の合成}

(1972 年8月 2 日受理)

潮 “真 澄・住 吉 義 博*

$\mathrm{Ca}(\mathrm{OH})_{2}$ あるいは $\mathrm{CaCO}_{3}$ と $\mathrm{SiO}_{2}$ の混合物を用い, テスト・チューブ型ボンベあるいはオートクレーブによって, 温度 $350 \sim 900^{\circ} \mathrm{C}$, 圧力 $10 \sim 1000 \mathrm{~atm}$ ，保持時間最高 2 週間の条件下で foshagite 織維を水熱合成した。混合物は白 金カブセルの中へ充テンした。合成試料はX線回折法, 偏光顕徽鏡, 電子顕微鏡, 俨折率測定などで調べた。Foshagite 㶓維の安定領域を調べたこの埸合 $\mathrm{pH}$ は大体 $6.8 \sim 7.2$ であった。 foshagite は $1000 \mathrm{~atm}$ で 400〜800 安定であった。同圧で大体 $850^{\circ} \mathrm{C}$ 以上では, wollastonite と rankinite が得られた。大体 $350^{\circ} \mathrm{C}$ 以下では xonotlite と hillebrandite が結晶相であった。foshagite 㵶維の長さ恃合成温度，压力の上䄯とともに增大する傾向が認

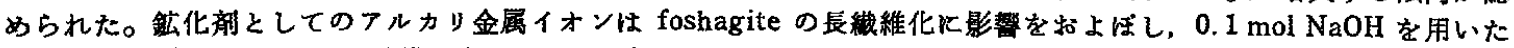
场合，最大 $670 \mu$ ぐらいの織維が合成できた。foshagite の長維䄉化への鉱化剂の傾向はつぎのとおりであった。 $\mathrm{NaOH}>\mathrm{KOH}>\mathrm{LiOH}$

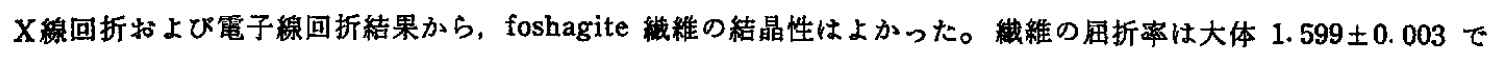
あった。

\section{1 腥 带}

近年, 人工軽骨材料, 保温, 防音, 断熱材料など $\mathrm{CaO}-\mathrm{SiO}_{2}$ $\mathrm{H}_{2} \mathrm{O}$ 系鉱物織維がよく用いられている。

Foshagite についての研究は少なく, foshagite は 1925 年,

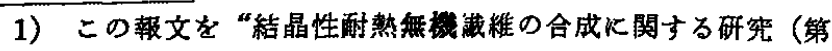
1 報)”とする.

* 群馬大学工学部韵分子化学科, 桐生市天神畉
Eakle2) により，California 州の Cŕestmore で発見され，その 後, 1958 年, Gard と Taylor ${ }^{3}$ により水熱合成された。彼らは $500^{\circ} \mathrm{C}, 400 \mathrm{~atm}, 14$ 日間の条件で, 合成ランカイナイト(rankinite, $3 \mathrm{CaO} \cdot 2 \mathrm{SiO}_{2}$ )を水熱処理することにより, foshagite を得 ている。

本研究は㵶維状晶であり，酎熱性が非常にすぐれていると思わ

2) A. S. Eakle, Amer. Mineral, 10, 97(1925).

3) J. A. Gard, H. F. W. Taylor, ibid., 43, 1(1958). 
れるフ*シャジァイト (foshagite, $4 \mathrm{CaO} \cdot 3 \mathrm{SiO}_{2} \cdot \mathrm{H}_{2} \mathrm{O}$ ) の水熱合 成を行ない，その合成条件および長蟣維化への基礶的知見を得る 目的で行なった。その結果を得たのでここに報告する。

\section{2 实 験 試 料}

出発原料としてはカルシウム源に市肘特級試薬, 水酸化カルシ ウムあるいは炭酸カルシウム，ケイ秦源沈沈降媻無水ケイ酸を用 Wた。

Foshagite の化学組成について, 1925 年. Eakle2) は, $5 \mathrm{CaO}$ $3 \mathrm{SiO}_{2} \cdot \mathrm{H}_{2} \mathrm{O}$ (orthorhombic), 1941 年 Jander と Franket) は $3 \mathrm{CaO} \cdot 2 \mathrm{SiO}_{2} \cdot \mathrm{H}_{2} \mathrm{O}, 1958$ 年, Gard 之 Taylors) $14 \mathrm{CaO} \cdot 3 \mathrm{SiO}_{2}$. $\mathrm{H}_{2} \mathrm{O}$ (monoclinic pseudo-cell) と Belov') は $4 \mathrm{CaO} \cdot 3 \mathrm{SiO}_{2} \cdot 1.5 \mathrm{H}_{2} \mathrm{O}$ としている。その後, Gard 5 (9) Mamedov 5の式について論評している。

以上の上らに，一部の人をのぞいて，報告者逢炕よって $\mathrm{CaO}$ $\mathrm{SiO}_{2}$ 比が一定しない。ここでは Taylor らと, Mamedov らの 結果を採用して， $\mathrm{CaO} / \mathrm{SiO}_{2}$ 比を 4/3 ととり，粉末を調合した。 $\mathrm{H}_{2} \mathrm{O}$ Kついてはここで一応 Taylor らの化学組成式を採用し た。

粉末は混合機を用い，10 時間乾式湿合したのち、エタノール を使用して湿式混合を 5 時間行なった。調合試料はあらかじめ作 製してある白金チューブの中へ所定量充テンした。

\section{3 実 験 装}

水熱合成装置にはオートクレーブ（ステンレス鋼製，内容積約 $90 \mathrm{ml}$ ) とテストチューブ型ボンベ（ステライト製，内容䅡約 7 $\mathrm{m} l)$ を用いた。温度測定は白金-白金・13\% ロジウム，あるいは クロメルーアルメル熱電対で行なった。代力は Bourdon 型轨力計 で誖み取った。白金チューブの大きさは，オートクレーブの場合 は $18 \phi \times 50 \mathrm{~mm}$, テストチューブ式ボンベでは $5 \phi \times 50 \mathrm{~mm}$ で ありここの中実験試料を充テンし上部を折り曲げた。このため に容器内の充テン水は自由淿金チューブ内に出入りできる状態 であった。

合成条件は, 温度 $350 \sim 900^{\circ} \mathrm{C}$, 圧力 $10 \sim 1000 \mathrm{~atm}$, 保持時間 最高 14 日間, $\mathrm{pH}$ 值は 5.0 11.0の範团内で行なった。合成試

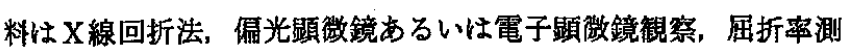
定なとで調べた。

\section{4 実 験 結 果}

\section{1 foshagite の安定領域}

foshagite の安定領域についてはいままでて 報告されていない ようである。これを知ることが先決の問題である。カルシウム源 に主としてて水酸化カルシウムを用いた実験㢤料を使用した。充テ ン水の $\mathrm{pH}$ 值注泳汴中性腹調整した。

水效合成後，白金チューブ内の試料を観察すると，図 1 のよう になる。図1はテストチューブ式ボンべを用いた結果である。充 テン試料嘼が多い場合（約 $0.3 \mathrm{~g}$ ) は合成後図 1 (a) のようKな

4) W. Jander, B. Frankle, Z. Anorg. Allg. Chem., 247, 161(1941).

5) Kh.S. Mamedov, N. V. Belov, Dokl. Akad.Nauk SSSR, 121, 901 (1958).

6) J. A. Gard, H. F.W. Taylor, Nature, 183, 171(1958); Silikat Tech., 11, 396(1960).

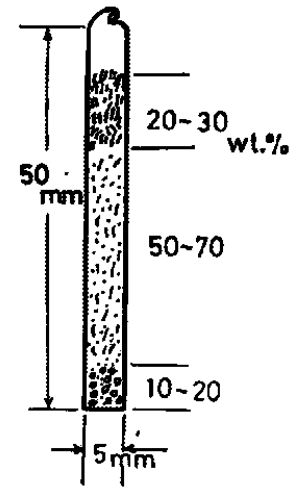

(a)

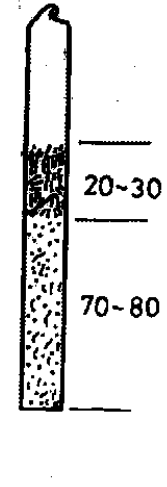

(b)
Fig. 1 Schema of specimen conditions after hydrothermal experiment

ク, 少小い場合（約 $0.1 \mathrm{~g}$ 以下）では（b）の上ら飞観察され た。（a ）（b）いずれの場合も，長織維は白金チューブの上部分 にできやすく，大体 20〜30 wt\% 程度であった。（a）図は，中

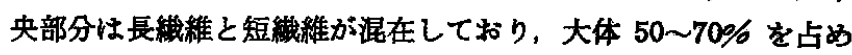
ていた。下部分は短織維と他の鉱物，あるいは原料の混在したす のであった。約 10〜20\%であった。以上のようにだいたい3層 に分別していた。上部分と中央部分の 2 㕌にる，いずれるわずか ではあるが，織維状晶の他们別の鉱物が存在していた。この鉱物 飞ついてはいまのところ明らかではない。一方，充テン量の少な い（b）の場合恃，だいたい2 層にわかれ，上層が長織維が多い 部分，下層が長緎維と短縺維の混在した部分である。この場合す （a）と同様に緎維状晶の他飞少量の伴生鉱物が認められた。

長轼維は白金チューブ外の白金を折り曲げたところたる時折り 成長していた。

因 2 飞X線回折図の一例を示す。1000 atm，7 日間の一定処理

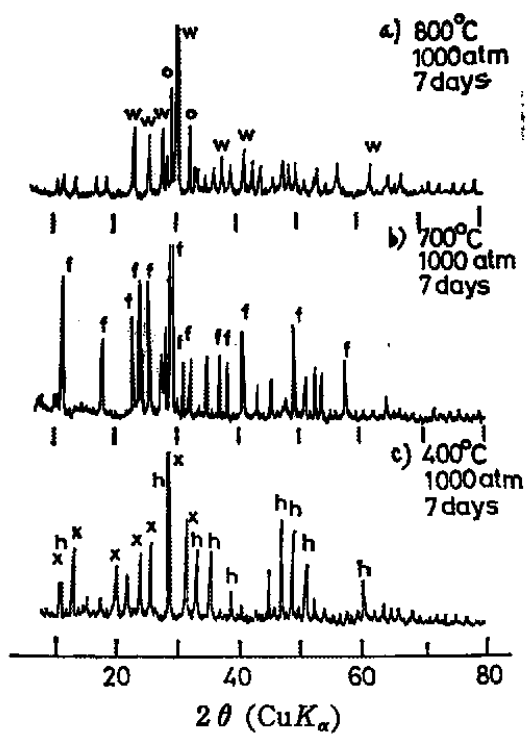

Fig. $2 \mathrm{X}$-ray powder diffraction patterns of each samples

w : Wollastonite, $f$ : Foshagite, $h$ : Hillebrandite, $\mathrm{x}:$ Xonotlite 
条件下で行ない，(a) は $800^{\circ} \mathrm{C}$ 処理のX線回折図であり, 四か ら明らかなよらにオラストナイト (wollastonite, $\mathrm{CaO} \cdot \mathrm{SiO}_{2}$ ， イ灰石）か生成していることがかかる。その他，オラストナイト の回折線にあまり重なっていないと考えると、ランカイナイト (rankinite, $3 \mathrm{CaO} .2 \mathrm{SiO}_{2}$ ) が生成していると思われる。このは が少数の小さい回折線が認められたが，これらの回折線につい てはいまのところ明らかではない。

（b）壮 $700^{\circ} \mathrm{C}$ 処理のるのであり，大部分 foshagite の回折線 が主であり，他伴生泒物が少量認められたが，いまのところ明 らかではない。

(c) は $400^{\circ} \mathrm{C}$ 処理のるのであり, xonotlite と hillebrandite が主生成釷物であることがわかる。（a ）（b）と同様炕少量の伴 生篗物が認められたが, 回折線が弱いのでいまのところ同定不可 能であった。

X線回折，顕徽覬観察結果から考之て，foshagite の安定敃域 は図3のよ5に示される。四から明らかなよらに，たとえば 500 atm では, 400 750 $\mathrm{\circ}$ の籁囲内で foshagite が唯一の安定相で ある。 $800^{\circ} \mathrm{C}$ 以上では wollastonite, rankinite, その他に少量の 伴生鉱物, $400^{\circ} \mathrm{C}$ 以下で仕 xonotlite, hillebrandite, 少量の他 の伴生鉱物が生成した。X印は Gard, Taylor らとよると，常 压下 $750^{\circ} \mathrm{C}$ 以上加熱すると foshagite $か$ wollastonite, $2 \mathrm{CaO}$. $\mathrm{SiO}_{2} ， \mathrm{H}_{2} \mathrm{O}$ 火分解すると報告している点である。しかし $2 \mathrm{CaO}$. $\mathrm{SiO}_{2}$ は確認されていない。一方, Mamedov, Belov ら5)はやは り $750^{\circ} \mathrm{C}$ で wollastonite， $\mathrm{CaO}, \mathrm{H}_{2} \mathrm{O}$ 飞分解すると報告してい 万。

本実匬結果では水熱下のために過剩の水が存在し, 比較するこ とは困難であるが， wollastonite 汢彼らの結果と同样牲生成した が，他の主生成鉱物は $2 \mathrm{CaO} \cdot \mathrm{SiO}_{2}$ あるいは $\mathrm{CaO}$ と違い, rankinite が生成した。

\section{2 温度・过力の影䇾}

図 3 の結果を利用して foshagiteの長綞維化への基整的研究を 行なった。

高温高压处理啳，合成試料を 4 等分化し，おの括の 4 枚のプレ

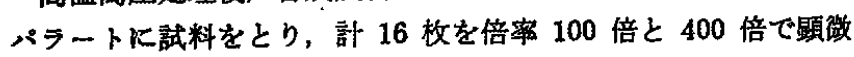
鏡親察を行ない，長織維を搜した。その結果を因 4 亿示す。 $\mathrm{pH}$

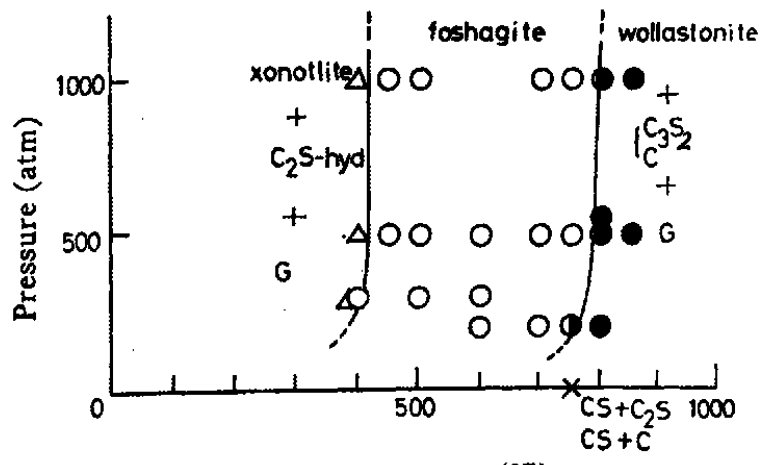

Temperature $\left({ }^{\circ} \mathrm{C}\right)$

Fig. 3 Stability region of foshagite

$\mathrm{C}_{2} \mathrm{~S}: 2 \mathrm{CaO} \cdot \mathrm{SiO}_{2}, \mathrm{C}_{8} \mathrm{~S}_{2}: 3 \mathrm{CaO} \cdot 2 \mathrm{SiO}_{2}$, hyd : Hydrate,

$\mathrm{G}:$ Gas, $\mathrm{C}: \mathrm{CaO}, \mathrm{S}: \mathrm{SiO}_{2}$

$\triangle:$ Xonotlite $+\mathrm{C}_{2} \mathrm{~S}-\mathrm{hyd}+\mathrm{G}, \mathrm{O}:$ Foshagite,

: Wollastonite $+\left\{\begin{array}{l}C_{g} S_{2} \\ C\end{array}\right.$ はだいたい中性であった。罒中，foshagite 紼維の長さを直径で

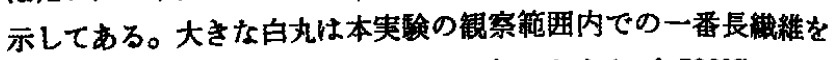
示し、黙丸はだいたいの平均値を示す。たとえば $500^{\circ} \mathrm{C}, 1000$ atm， 7 日間の年件下では，長溨維恃だいたい $120 \mu$ 程度であり， 平均値住 $25 \mu$ 程度であった。压力・保持㭙間同一で $750^{\circ} \mathrm{C}$ 処

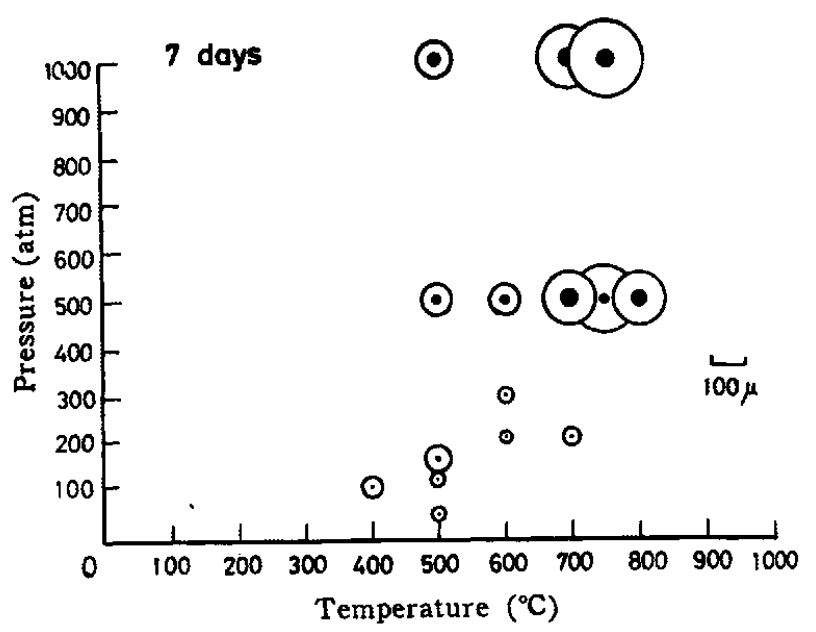

Fig. 4 Effect of synthesized temperatures and pressures on the foshagite fiber length

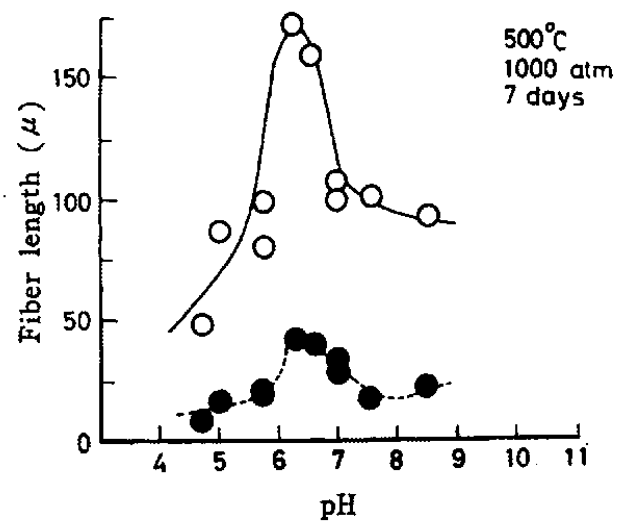

Fig. 5 Effect of $\mathrm{pH}$ values on the foshagite fiber length

$O$ : Maximum fiber length, : Average fiber length

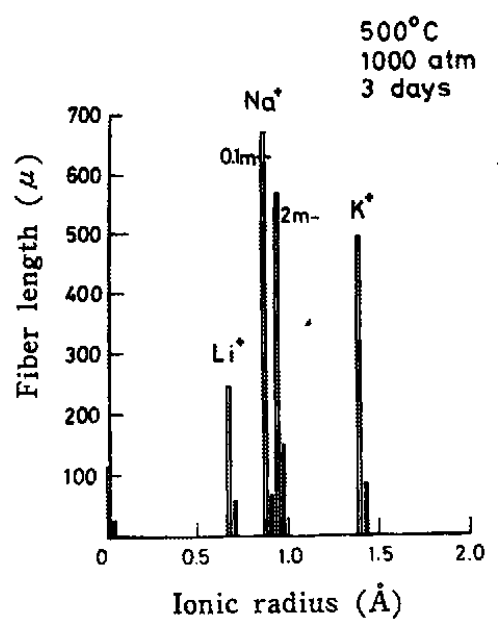

Fig. 6 Effects of each mineralizers on the foshagite fiber length 
理では $230 \mu$ 程度の辰絒維が得られた。平均値はだいたい $30 \mu$ 程度であった。

図 4 から明らかなよらに，例外ああるよらであるが，だいたい 合成温度の上昇とともに収率が高く，長絨維ができる傾向があっ た。同様に合成圧力についてす同じ傾向が認められた。これらの 傾向は織維長の平均値についても認められた。

\section{$4.3 \mathrm{pH}$ の影翌}

図 4 で得られた長瀻維は $\mathrm{pH}$ 值がだいた中性（pH=6.8〜 $7.2)$ である水溶液で処理して得たものであった。 $0.1 \mathrm{~N} \mathrm{HCl}$ あ るいは $0.1 \mathrm{~N} \mathrm{NaOH}$ 溶液をごく少量用いて $\mathrm{pH}$ を $5.0 \sim 11.0$ K 適当に調整した。合成後の $\mathrm{pH}$ 值と緘維の長さとの関係を図 5 に 示す。図中，白丸は長織維の長さを，黒丸は平均の長さを示す。 たとえば図 5 のように foshagite の生成条件を $500^{\circ} \mathrm{C}, 1000 \mathrm{~atm}$, 7 日間と一定にした場合, $\mathrm{pH}$ 值が $6.0 \sim 7.0$ の範囲内で foshagite の高収率および長㵶維が得られた。図から明らかなように
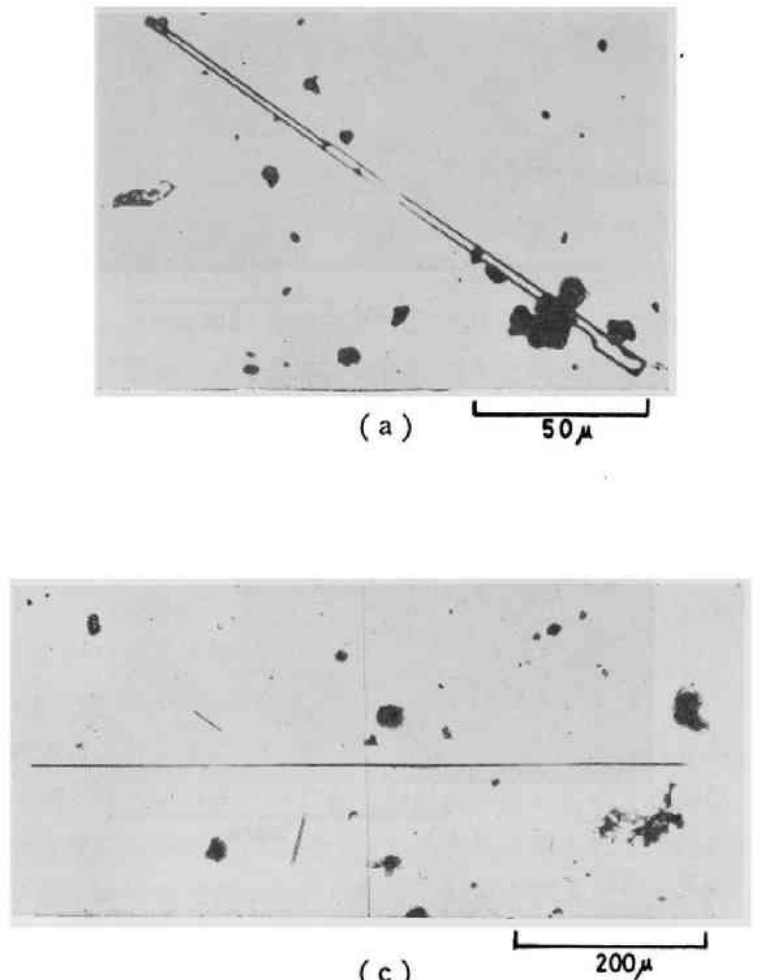

(c)

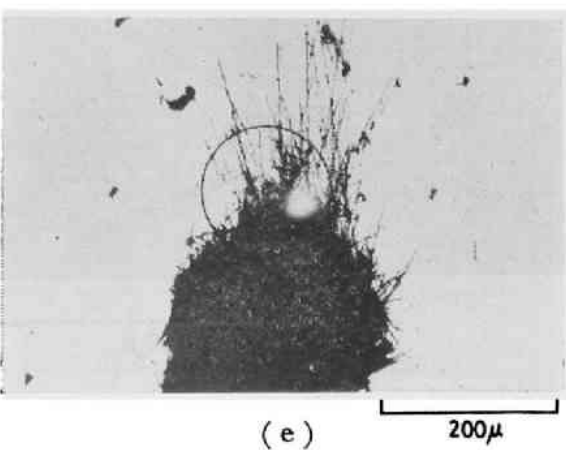

Fig. 7-1 Microscopic photographs of each synthesized samples

(a) : $700^{\circ} \mathrm{C}, 1000 \mathrm{~atm}, 7$ days, about $180 \mu$

(c) : $500^{\circ} \mathrm{C}, 1000 \mathrm{~atm}, 7$ days $(0.1 \mathrm{~N} \mathrm{NaOH})$, about $670 \mu$

(e): The same conditions with (d)
$\mathrm{pH}$ 值が 6.2 付近でもっとも長い織維が得られた。しかし 4.4 で述ベるように，かなりアルカリ性溶液を用いて foshagite を合 成しても，長纎維ができることから，図 5 は $\mathrm{pH}$ 値が高くなるに つれてもら一つのピーク（山）が存在するよらである。

\section{4 添加剂の影響}

アルカリ 1 価金属イオンを用いて, foshagite の長織維化への 影響を調べた。 $500^{\circ} \mathrm{C}, 1000 \mathrm{~atm}, 3$ 日間の条件下で, $0.1 \mathrm{~N} \mathrm{NaOH}$ および $2 \mathrm{~N} \mathrm{NaOH}$ 溶液, $2 \mathrm{~N} \mathrm{KOH}$ と $2 \mathrm{~N} \mathrm{LiOH}$ 溶液を用いて 水熱合成を行なった。四6に結果を示す。顕微鏡での測定条件は 4.2 と同じである。図中, 白い棒状グラフは長緎維の長さを示し, 黒いのは平均の㵶維長を示す。上に述ぺた同一合成条件で, $\mathrm{pH}$ のみ 7.0 付近で行なった無添加の場合は, だいたい $120 \mu$, 平均 $25 \mu$ 程度の織維長を示したが，四から明らかなよらに，各種の 添加剂の場合でも長紻維が得られた。長緘維が得られた添加剤の 傾向は
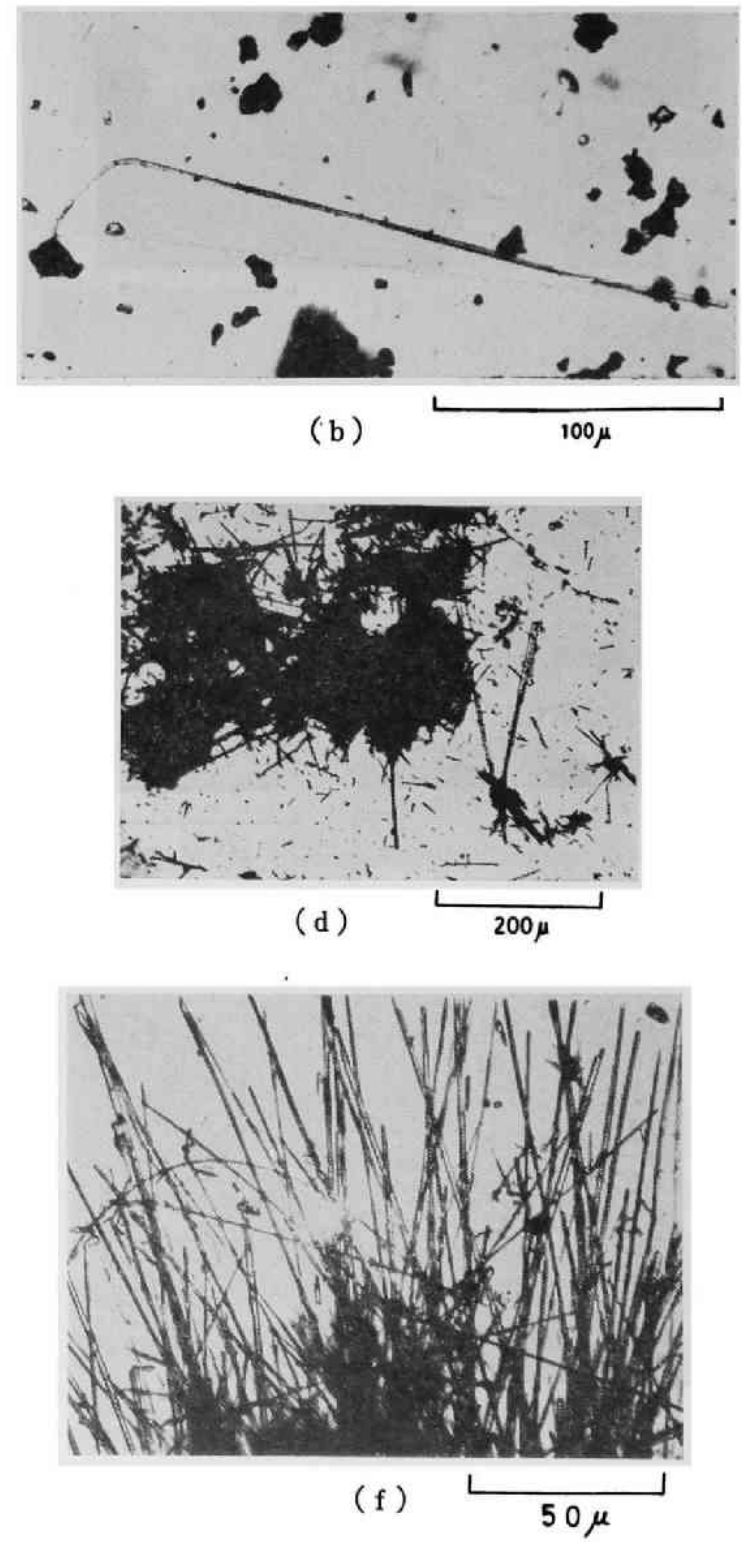

(b) : $750^{\circ} \mathrm{C}, 500 \mathrm{~atm}, 7$ days, about $230 \mu$

(d) : $500^{\circ} \mathrm{C}, 1000 \mathrm{~atm}, 3$ days $(2(\mathrm{~N} \mathrm{NaOH})$

(f) : An enlarged photo of (e ) 


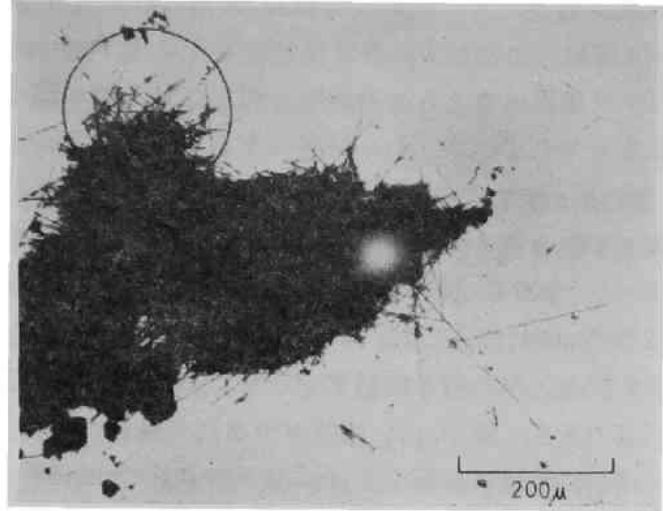

(g)

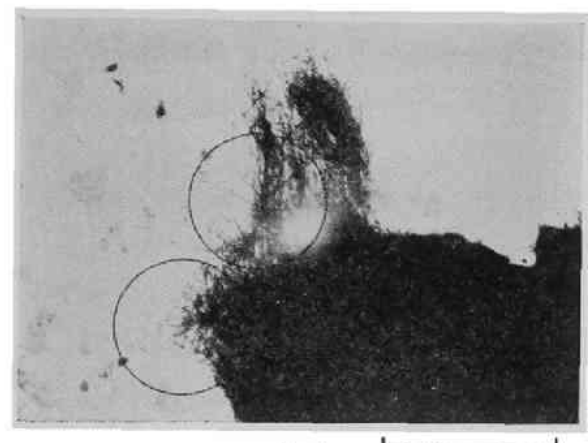

(i)

$200 \mu$
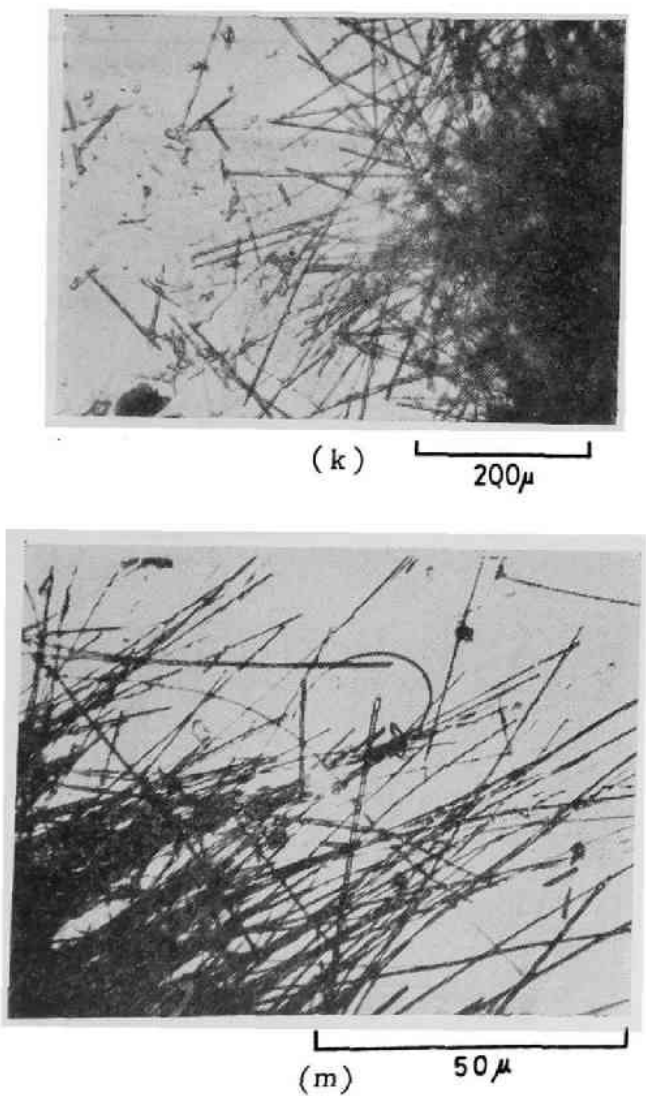
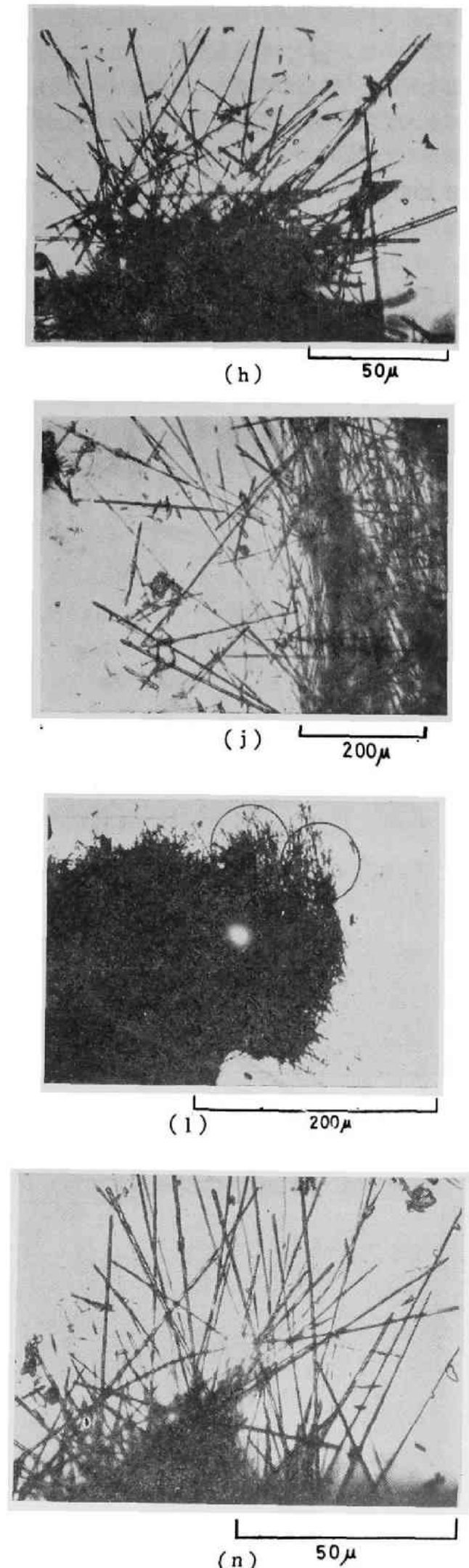

Fig. 7-2 Microscopic photographs of each synthesized samples

(g) : $500^{\circ} \mathrm{C}, 1000 \mathrm{~atm}, 3$ days $(2 \mathrm{~N} \mathrm{KOH})$

(i): The same conditions with $(\mathrm{g})$

(k): An enlarged photo of (i)

$(\mathrm{m})$ : An enlarged photo of (1) $(h)$ : An enlarged photo of $(g)$

(j) : An enlarged photo of (i)

(1) : $500^{\circ} \mathrm{C}, 1000 \mathrm{~atm}, 3$ days $(2 \mathrm{~N} \mathrm{LiOH})$

$(\mathrm{n})$ : An enlarged photo of (1) 
$\mathrm{NaOH}>\mathrm{KOH}>\mathrm{LiOH}$

の順であった。

$0.1 \mathrm{~N}$ と $2.0 \mathrm{~N} \mathrm{NaOH}$ 溶腹を用いた場合、両者の間に長㵶維 の長さ，平均の長さに差異が認められたが，実験回数が少なく， また $\mathrm{NaOH}$ の濃度变化による舆絨維化への 系統的実験を行なっ ていない関係上，いまのところ詳細に論議できない。

\section{5 顕微鏡観察}

倍率 100 倍と 400 倍を用いて影微鏡観察を行なった結果を図 7 に示す。（b）図から判断して，foshagite 㵶維はかなり柔軟性 が存在することが明らかである。（c）図は本実験中で最長の絨維 であり、約 $670 \mu$ 程度であった。（a ～( c ）図から明らかなよ らに foshagite 㵶維以外飞他の鉱物が存在していることがわか る。（d）図は長織維と短織維が淈り合っていた層から影微鏡用試 料を採取したるのである。 $200 \mu$ 程度の長繊維, $50 \mu$ 程度，それ 以下の織維の存在が認められる。（e ）は（d）と同一試料であり， 長織維のみの生成部分から得たものである。黒い部分は長織維束 である。黑丸部分を拡大すると（f）図のようになる。（f）図か ら明らかなよらに割合に絨維の太さもそろっている foshagite 絨 維が認められる。湾曲している織維が認められるが，上に述べた ようにかなり柔軟性があるといえよう。（（）図は鉱化剂として $2 \mathrm{~N} \mathrm{KOH}$ 溶液を用いた場合である。影微鏡試料は長㵶維が生成 した部分から採取したすのである。黒い部分は㵶維の集束したも のである。同様にして黒丸部分を拡大すると，(h)図のように無 数に緎維が認められる。（i ）図は $(\mathrm{g})$ と同一試料であり，長緎 維生成部分の他の場所から採取したものである。同様に黒丸部分 を拡大すると（j）と（k）罒のようになる。長緘維束が認められ

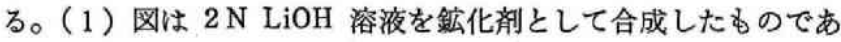
る。 $(\mathrm{m})$ と $(\mathrm{n})$ 図はその拡大図である。 $(\mathrm{m})$ 四から明らかなよ らに，半円型に湾曲した纎維が認められることから，上に述べた よらにかなり柔軟性があることが認められる。

\section{6 電子顕微鏡観察}

日本電子株式会社製電子顕微鏡装置（JEM-AD-3）を用いた。 カーボン蒸着膜法により作製した試料の直接観祭を行ない, 同時 飞制限視野電子線回折を行なった。被検試料としては短蟣維が主 として生成した部分から採取した。結果を図 8 に示す。約 $1 \sim 5 \mu$ 程度の織維状(?)晶が無数に認められた。電子線回折図形はすべ て繊維軸に垂直方向（ $c$ 軸方向）から電子線を照射して得られた あのである。層交互に強い回折点群と弱いそれが認められだ。こ， れは foshagiteの結晶構造の特徵である。また結晶化度は回折点 のようすから考えてかなり高いことが認められた。

\section{7 届折率測定}

アタゴ光学器機株式会社 Abbe 製屈折計を用い, 水温 $20^{\circ} \mathrm{C} K$ おいて foshagite 繊維の属折率を測定した。浸液は一般の市眅溶 液を用いた。湘定結果は平均 $1.599 \pm 0.003$ であり，Gard ら゙3 の測定結果の $1.598 \pm 0.02$ の值と同一であった。

\section{5 考察}

出発原料としては 2 で述べたように，カルシウム源としては $\mathrm{Ca}(\mathrm{OH})_{2}, \mathrm{CaCO}_{3}$, ケイ素源には沈降製 $\mathrm{SiO}_{2}$ を用いた。水に対 する溶解度は, $\mathrm{SiO}_{2}$ の場合, 温度上昇ととすに増加する7)。高温

7）日本化学会編, “化学便筧”, 丸善 (1966) p. 629, 647, 649.
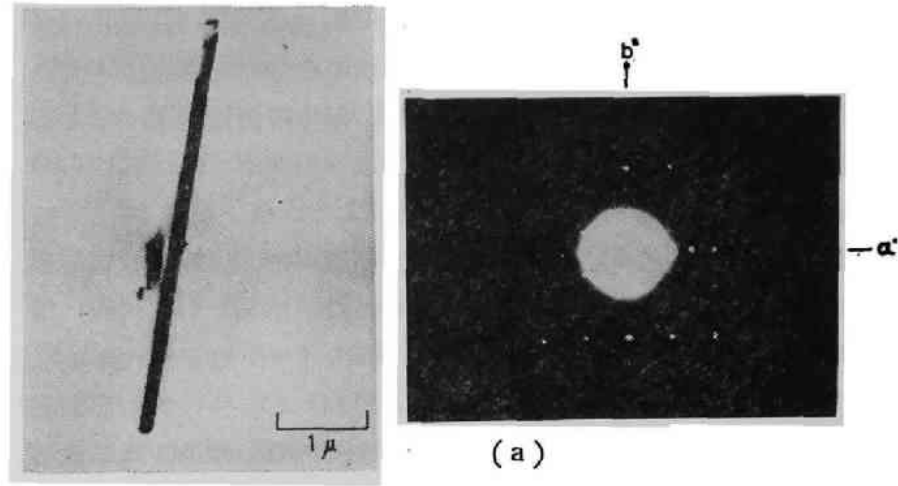

(a)
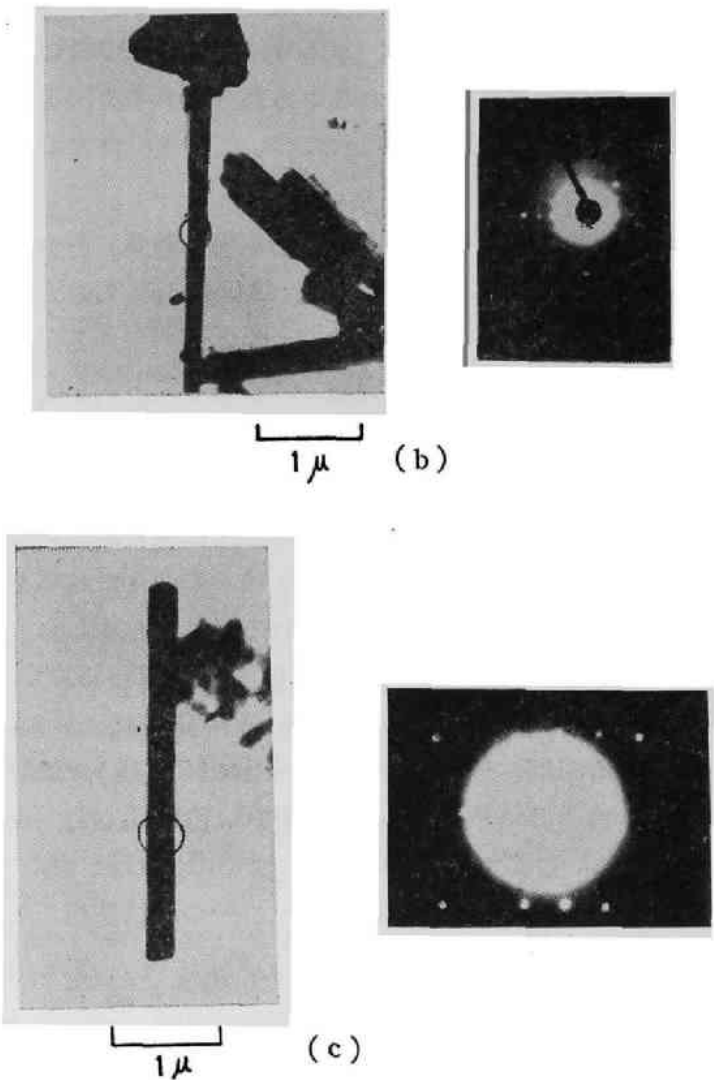

(c)

Fig. 8 Electron micrographs of each synthesized samples

(a) : $500^{\circ} \mathrm{C}, 1000$ atm, 7 days

(b) : The' same conditions with (a)

(c): The same conditions with (a)

高压下では石英の溶解度は，750 atm までの 圧力下では，ほぼ $360 \sim 400^{\circ} \mathrm{C}$ 付近が溶解度が最大值を示し, この温度以上では溶 解度は減少する傾向がある。 $800 \mathrm{~atm}$ 以上では溶解度は温度の上 昇ととすに増加する傾向があることが報告されている8。一方， $\mathrm{CaCO}_{3}$ の場合は， $\mathrm{CO}_{2}$ を含まない水に対しては常圧下で温度の 上昇とともに溶解度は上昇する傾向があるか゚， $\mathrm{CO}_{2}$ を含む水に対 しては $\mathrm{CO}_{2}$ 分圧により異なるが，温度の上昇とともに溶解度は 減少する傾向がある7)。 $\mathrm{Ca}(\mathrm{OH})_{2}$ の場合も $\mathrm{CaCO}_{3}$ とほぼ同様の 傾向がある。 $\mathrm{CaCl}_{2}, \mathrm{CaBr}_{2}$ などの 八ロゲン化物，硝酸塩などは 水に対する溶解度は大きいが，水溶液中に多種類の陰イオンが存 在することになり,陰イオンの効果も無視できなくなることから, なるべく $\mathrm{CO}_{3}{ }^{2-}$ イオン, $\mathrm{OH}^{-}$イオンなどのアニオンにしぼった。

8) G. C. Kennedy, Econ. Geol., 45, 629(1950). 
この理由から上に述べた $\mathrm{Ca}(\mathrm{OH})_{2}, \mathrm{CaCO}_{8}$ を出発原料に用いた。 主として前者を使用した。これら 2 種類の成分の高温高压下での

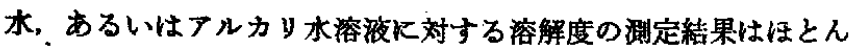
どない状態である。蹦界温度，王力以上の条件下ではなおさらの ことである。

高温高王処理後，X線回折図形下出発原料の回折線が蝺められ ないことから，高温高压下ではなんらかのイオンの形 (状態)て 溶解し、 $\mathrm{Ca}^{2+}$ イオン, $\mathrm{Si}^{4+}$ イオン, $\mathrm{OH}^{-}$イオンなどが化学結合 して化合物（鉱物）が生成したすのと思われる。すなわち高温高 匡下ではこれらの難溶性無機合物の水，あるいはアルカリ水溶 液に対する溶解度はかなり高いことが推定されらる。

出発原料 $\mathrm{CaCO}_{3}$ ，あるいは $\mathrm{Ca}(\mathrm{OH})_{2}$ を用いた場合の差異は，

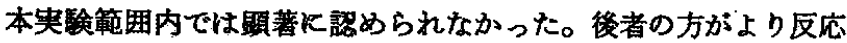
性がよいよらに推定されるが，これについての椧討はよりきめ細 い㬰験が必要であろう。

Foshagite の構造式については種々の報告があり，その式も違 っているが，だいたい Gard らの式と，Mamedov らの式にまと められよう。雨式の $\mathrm{Ca}: \mathrm{Si}$ の此性 $4: 3$ と同一であるが、 $\mathrm{H}_{2} \mathrm{O}$ のモル比のみが違っている。本実験では水熱合成方式をとり, 構 造水上りは大過䣋の水を添加するために, 出発原料の調合時に $\mathrm{H}_{2} \mathrm{O}$ のモル比はあすり関係がないと思われる。

Foshagite の安定領域についてはいままで飞報告がないようで ある。Taylor") は $\mathrm{CaO}$ と $\mathrm{SiO}$ の比を種々飞変光た試料を用い て水熱合成し，最終生成物として王われる結晶相を示した。とれ 火よると，foshagite は $300^{\circ} \mathrm{C}$ 以上で生成し， $275 \sim 300^{\circ} \mathrm{C}$ の範 囲では xonotlite $+\mathrm{C}_{2} \mathrm{~S} r$-hydride, $175 \sim 275^{\circ} \mathrm{C}$ で柱 xonotlite + $\mathrm{C}_{2} \mathrm{~S} \beta$-hydride, $125 \sim 175^{\circ} \mathrm{C}$ では af willite $\left(\mathrm{C}_{3} \mathrm{~S}_{2} \mathrm{H}_{3}\right), 125^{\circ} \mathrm{C}$ 以 下では calcium silicate hydride (I) $\left(\mathrm{C}_{1 \sim 1.6} \mathrm{SH}_{0.5 \sim 2.8}\right)$ が 生成 するとしている。ここで C は $\mathrm{CaO}, \mathrm{S}$ は $\mathrm{SiO}_{2}, \mathrm{H}$ は $\mathrm{H}_{2} \mathrm{O}$ を示 す。foshagite の構造式から考慮すると，一つの結晶相（たとえ ば afwillite) のみ生成するのは赫かしいが，一応，生成結晶相 のみと考えられよう。

本実験結果では，低温領域はあまり詳細炕検討していないので 明確なことはいえないが， $400^{\circ} \mathrm{C}$ 以下では xonotlite $+\mathrm{C}_{2} \mathrm{~S}$-hyd-

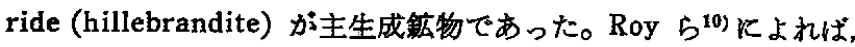
たとえば $1000 \mathrm{~atm}$ 付近では, xonotlite は $410^{\circ} \mathrm{C}$ 以上で wollastonite $+\mathrm{H}_{2} \mathrm{O}$ K分解する。この結果と本実験結果とよく一致し ているといえよう。

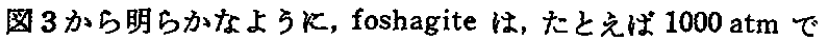
は 420 800 $80^{\circ} \mathrm{C}$ の範囲で安定相であった。 $800^{\circ} \mathrm{C}$ 以上では wollastonite $+\mathrm{C}_{8} \mathrm{~S}_{2}$ (rankinite) が声生成鉱物であった。

$$
\begin{aligned}
& 4 \mathrm{CaO} \cdot 3 \mathrm{SiO}_{2} \cdot \mathrm{H}_{2} \mathrm{O} \rightleftarrows \mathrm{CaO} \cdot \mathrm{SiO}_{2}+3 \mathrm{CaO} \cdot 2 \mathrm{SiO}_{2}+\mathrm{H}_{2} \mathrm{O} \\
& \text { (fohagite) (wollastonite) (rankinite) }
\end{aligned}
$$

のような反応が生じているすのと思われる。

天然産 foshagite の常圧下での脱水については Gard $5^{2)}$, Mamedov $ら^{\text {) }}$ が報告しており，前者は $750^{\circ} \mathrm{C} て ゙ \mathrm{CS}$ (wollastonite) $+\mathrm{C}_{2} \mathrm{~S}+\mathrm{H}_{2} \mathrm{O} \mathrm{K}$, 後者は同温度 $\tau$ CS $+\mathrm{CaO}+\mathrm{H}_{2} \mathrm{O}$ K分解

9) H. F. W. Taylor, Proc. Intern. Symposium on Reactivity of Solids, Gotherburg, II, 676 681(1954).

10) D. M. Roy, Amer. Mineral, 43, 1017(1958) ; D. A. Buckner, D. M. Roy, R. Roy, Amer. J.Sci., 258, 134(1960).
することを報告している。

$$
\begin{aligned}
& \mathrm{Ca}_{4} \mathrm{Si}_{3} \mathrm{O}_{\mathrm{v}}(\mathrm{OH})_{2} \rightleftarrows 2 \mathrm{CaSiO}_{3}+\mathrm{Ca}_{2} \mathrm{SiO}_{4}+\mathrm{H}_{2} \mathrm{O} \\
& \mathrm{Ca}_{8}\left[\mathrm{Si}_{8} \mathrm{O}_{17}\right](\mathrm{OH})_{8} \rightleftarrows 6 \mathrm{CaSiO}_{8}+2 \mathrm{CaO}+3 \mathrm{H}_{2} \mathrm{O}
\end{aligned}
$$

水熱下と大気压下とで注条件が違らが，いずれにして wollastonite が生成する点で性本実験結果と同じである。Gard らの 主張する $\beta-C_{2} S$ は本 X 線回折四形で認められず，また wollastonite の回折線とあまり重なっていないと考えると，wollastonite 以外の回折線注 $\mathrm{C}_{8} \mathrm{~S}_{2}$ (rankinite) の回折線 とほとんと 一致した。少し回折線が重なっていると仮定すると $\mathrm{CaO}$ の可能 性がある。

Wyllie と Tuttle ${ }^{11)}$ によると， $\mathrm{CaO}-\mathrm{H}_{2} \mathrm{O}$ 系において，たとえ は $1000 \mathrm{~atm}, 820^{\circ} \mathrm{C}$ 以下では $\mathrm{Ca}(\mathrm{OH})_{2}+$ 液相十気相 $\left(\mathrm{H}_{2} \mathrm{O}\right)$, 同 压飞て $850^{\circ} \mathrm{C}$ 以上では $\mathrm{CaO}+\mathrm{Ca}(\mathrm{OH})_{2}+$ 気相，上り低压下で, それ望れの温度では $\mathrm{CaO}+\mathrm{Ca}(\mathrm{OH})_{2}$ 気相, $\mathrm{CaO}+$ 液相十気相比 なることを報告している。これらの結果から考虑すると、 $\mathrm{CaO} か ゙$ X線回折図形火喼められても不思議ではない。しかし $1000 \mathrm{~atm}$ の水蒸気压下で, $\mathrm{Ca}(\mathrm{OH})_{2}$ は約 $835^{\circ} \mathrm{C}$ 以下では液体であり, 共 存する $\mathrm{H}_{2} \mathrm{O}$ が多くなるにつれて，液体になる温度が $820^{\circ} \mathrm{C}$ 以下 となること，また $\mathrm{H}_{2} \mathrm{O}$ が大過剩に存在することなとから考兄て， $\mathrm{CaO}$ の状態で存在する可能性についてはまだ問題が残る。

Foshagite の長織維化には温度，代力扰よび $\mathrm{pH} の$ 影響が認め られた。本実験結果から考兄て，前者二つは高いほと，長織維が 得られる傾向が認められた。しかし後者は $\mathrm{pH}$ 值が 6.2 付近を 一つのピークとし(図5)，いったん樴維の長さが滅少するが，さ らにアルカリ側になるにつれてるら一つのピークが存在するよう

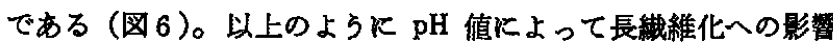
が翼なってくる。これについての理由はいまだ明らかではない。

添加剂の影響もかなり認められた。本研究ではとくにアルカリ 金属元素を用いたが，無添加の場合と比較して foshagiteの長緎

\section{Foshagite $\mathrm{Ca}_{4} \mathrm{Si}_{3} \mathrm{O}_{9}(\mathrm{OH})_{2}$}

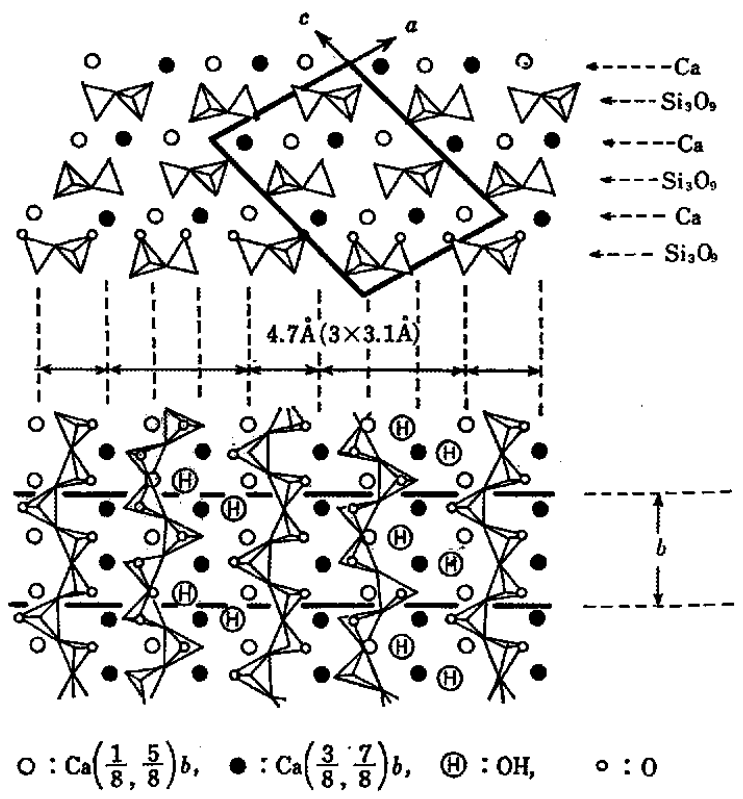

Fig. 9 Crystal structure of foshagite

11) P. J. Wyllie, O. F. Tuttle, J. Amer. Ceram. Soc., 42, 449(1959). 
維が得られた。このようにアルカリ 1 価金属イオンの添加により foshagite の長蟣維化が促進したが，これら金属イオンと CaO$\mathrm{H}_{2} \mathrm{O}, \mathrm{SiO}_{2}-\mathrm{H}_{2} \mathrm{O}$ ，あるいは $\mathrm{CaO}-\mathrm{SiO}_{2}-\mathrm{H}_{2} \mathrm{O}$ 系などの状態図が一部 を除き皆無であること，上述べたよらに生成機構の解明につい ての実絤を行なっていないので明らかなことはいい難い。

因 9 K foshagite の結晶構造6) を示す。1 洒金属イオンの添加 により，無添加の場合よりる $a ，$ あいは $c$ 軸方向に成長してい る織維す認められたが，その量はごくわずかであった。また少量

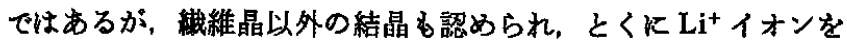
含む我溶液を用いた場合は他の鉱物ができやすいようであった。 和をらくリナウムを含も化合物であろう。

X線回折法，電子線回折法などの結果から，合成 foshagite 織 䧽の結晶性は良好であった。図8から明らかなように偶数の層線 は強い反射を示し，奇数の啳線は弱い反射を示している。これら
は foshagite 瀻維晶の特徵である。

屆折率の測定結果 (4.7)，X 線回折および電子線回折結果なと から考えると，foshagite 織維が生成したと考えられる。図 7 K 示した維維群の 1 本 1 本を測定したわけではないので, 全部が foshagite 織維であるとは断定し難いが，よく似た紻維晶の屈折 率測定之電子線回折結果，また集合体ではあるがX線回折結果か 5, foshagite 織維の安定領域内では okenite $\left(\mathrm{CS}_{2} \mathrm{H}_{2}\right)$, nekoite $\left(\mathrm{CS}_{2} \mathrm{H}_{2}\right)$, xonotlite $\left(\mathrm{C}_{6} \mathrm{~S}_{6} \mathrm{H}\right)$, hillebrandite $\left(\beta-\mathrm{C}_{2} \mathrm{SH}\right)$, tobermorite $\left(\mathrm{C}_{8} \mathrm{~S}_{6} \mathrm{H}_{9}\right)$ などの絨維状結晶の回折線が 認められないこと から, foshagite 瀻維のみであると推定し得る。

実験の一部を協力していただいた早川昌美君（現在，共和レザ

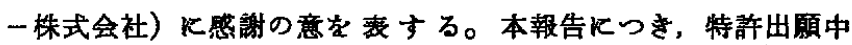
（屹願番号 47-057341）である。

\title{
Hydrothermal Synthesis of Foshagite (fiber) $\left(4 \mathrm{CaO} \cdot 3 \mathrm{SiO}_{2} \cdot \mathrm{H}_{2} \mathrm{O}\right)^{\dagger}$
}

\author{
Masumi Ushro and Yoshihiro Sumryoshr* \\ Department of Applied Chemistry, Faculty of Engineering, Gunma \\ University, Kiryu-shi, Gunma, Japan
}

Foshagite fiber was synthesized hydrothermally from mixtures of $\mathrm{Ca}(\mathrm{OH})_{2}$ or $\mathrm{CaCO}_{3}$ and $\mathrm{SiO}_{2}$ chemicals at temperatures ranging from 350 to $900^{\circ} \mathrm{C}$ under water vapor pressures of 10 to 1000 atm for maximum two weeks, using a test-tube type bomb or autoclave. The mixture was charged in a $\mathrm{Pt}$-capsule. The products were examined by $\mathbf{x}$-ray diffractometry, polarizing microscope method, electron microscopy, refractive index measurement etc..

Stability region of foshagite fiber was studied. In this case the $\mathrm{pH}$ of the solution after the reaction was adjusted to $6.8 \sim 7.2$. Foshagite was found stable at temperatures ranging from 400 to $800^{\circ} \mathrm{C}$ under the water pressure of $1000 \mathrm{~atm}$. Above about $850^{\circ} \mathrm{C}$ and the same pressure, wollastonite and rankinite were obtained. On the contrary, below about $350^{\circ} \mathrm{C}$, xonotlite and hillebrandite were stable crystalline phases. Foshagite fiber length had a tendency to increase with the elevation of synthesized temperatures and pressures.

Alkaline-metal ions added as the mineralizers influenced on the foshagite fiber length and the fiber having maximum length of $670 \mu$ could be synthesized, using water solution with 0.1 mole $\mathrm{NaOH}$. The effect of the mineralizers which had a great influence on the foshagite fiber length was as following order

\section{$\mathrm{NaOH}>\mathrm{KOH}>\mathrm{LiOH}$}

From the results of $\mathrm{X}$-ray powder diffraction and the electron diffraction patterns, foshagite fiber was found to have high crystallinity. Refractive index of foshagite fiber was about $1.599 \pm$ 0.003 .

$\dagger$ Study of the Synthesis of Crystalline Refractory Inorganic Fibers. I. 